ISSN: 2716-1277

e-ISSN: 2716-1269

Available online at TLIC https://jlic.iain-jember.ac.id/
Journal of Language Intelligence and Culture

Fakultas Tarbiyah dan Ilmu Keguruan

IAIN Jember

Vol 3, No.2, Page 93-106, December 2021

\title{
Online Learning Contract: A Way Disciplining Students
}

\author{
Sari Dewi Noviyanti, \\ UIN Walisongo \\ Email: Sari.dewi@walisongo.ac.id
}

\begin{abstract}
ARTICLE INFO
Article History:

Accepted: September 2021

Approved: December 2021

Published: December 2021

Key Words:

online learning, learning

contract
\end{abstract}

DOI: $10.35719 / j$ lic.v3i2.56

\begin{abstract}
The contract between teacher and student or what is often called as teacher-student agreement is one of the class management in applying student discipline. Good class management, especially in student discipline, is considered important in creating a conducive learning atmosphere. In conventional learning, teacher and student contracts regarding student discipline are related to how students' attitudes in participating in learning, such as students not being allowed to go around the class while learning is taking place, students are not allowed to be busy with other things besides those related to learning and others. At this time, when online learning or distance learning is applied, of course this contract is also undergoing changes. There is a disciplinary agreement between the teacher and students that adapts to distance learning conditions. This study aims to identify the learning discipline contract between students and teachers in distance learning. Questionnaires and interviews were used to collect data. The data were analyzed descriptively to get a description of the agreement between teachers and students in online learning and the type of agreement that commonly used. The findings show that the most widely regulation is related to student's obedience in following teacher's instruction in online class. This study also revealed that learning contract is an effective way to create a successful online learning based on teacher's perspectives.
\end{abstract}

\section{INTRODUCTION}

The COVID-19 pandemic outbreak has affected education system all around the world. This pandemic forces all education institutions to change their learning method, from face-to-face 


\section{JLIC}

interaction to distance computer or mobile device mediated interaction. This type of learning is known as e-learning. This sudden shift policy decision may become a challenge for both teacher and students. That is why the current research is conducted to find out how teacher and students adapt to the rapid change, especially related to their learning contract

Discussing about learning contract, it actually happens both in conventional class and online learning. However, due to a change in the form of classes from conventional to online learning, there are also changes in the form of learning contract. These changes include class rules and teacher-students agreement in online class.

One of the techniques that can be used in reducing problems of learning behavior is by preparing a learning behaviour contract. Learning contract is a technique aims to create a habituation for students to be independent learner and be responsible for their own learning, (Yusuf \& Legowo, 2007: 210). This contract includes modifying students own behavior interpreted as the application of principles time-tested learning to change, weaken / eliminate behavior not adaptive, as well as giving rise to and confirms adaptive behavior, (Wolpe, in Purwanta, 2015: 7). According to Yusuf \& Legowo (2007: 190), the contract is written agreement and agreement between "Modifier" (person / party who will do the behavior change process) with students who will be changed behavior he did. The content of the behavior contract should be understood by both parties involved in behavior contract, so that the desired objectives can be achieved.

The primary aim of this study is to examine online-class learning contract exist at Junior High School in East Java taken from teacher's point of view. The objectives of this study were to (1) provide types of learning contract applied in online-class, (2) identify the effectiveness of learning contract based on teacher's perspectives. Practically, the findings of this study could be a reference for counselling and guidance in the school context, especially for distance learning.

Some previous studies have revealed the effectiveness of learning contract as a strategy to increase positive potentials of students such as value acknowledgment, learning motivation, learning confidence, learning responsibility, leaning authority and learning satisfaction (Lewis, 2004). A research finding by Schwarzer, Kahn \& Smart (200o) also showed that encouraging 
independent learning and autonomous learning of students can be done through a learning contract. The study revealed that students having an intrinsic motivation to reach their learning output and outcome through the help of learning contract. A study by Little (2000) also found learning contract give many positive impacts on learners since its existence helps teacher and students to do a meaningful learning started from learning plan and learning evaluation. In addition, it provides teachers as well as learners with a continuously moving reference point against which to plot the progress of learning.

The use of learning contract also proposed by Lewis (2004) to increase college student's motivation in reading. The study found significant improvement of student's reading score through independent learning contract. The findings revealed that students with learning contract got a higher score compared to students with non-learning contract. Sun \& Shek (2012) mention that learning contract has been used and delivered satisfactory results in dealing behavioral problems such as mischievous behavior, disturbing behavior in elementary school children, college student behavior, as well other negative behavior. Learning contracts is a technique aims to train students to be able to control and direct his own learning behavior. This contract includes modify your own behavior interpreted as the application of principles time-tested learning to change, weaken / eliminate behavior not adaptive, as well as giving rise to and confirms adaptive behavior.

An improvement of motivation level among two group of students also found by Masdinah and Abdul Halim (2004a, 2004b). Their study revealed that learning contract could help teacher to promote student's learning autonom and learning independency. Student's perceptions towards independent learning also increased by the help of learning contract. Another study done by Lai (2007) found that the improvement of student's learning awareness by the help of learning contract. Learning contract manage students to be able to set up their own goals and have a clear picture of how to reach the them. Frank and Scharf (2007) conducted a research related to the impact of learning contract on student's behaviour and their academic achievement. They found that learning contracts make students more discipline. Students tend to be more responsible of their task and assignment and showed a positive improvement of their learning achievement. In short, learning 


\section{JLIC}

contracts is an effective and a low-cost strategy to help students to commit to their own learning. Self-directed as one of the aims of learning contract also found by a research done by Chyung (2007); Ismail and Yusof (2007) and by Sumiarsih (2019) which revealed learning contract promotes learning independency, learning autonomy able to decrease student's misbehaviour and help students to learn better and faster

E-learning is an innovation of technologies which has primary aim to improve education qualities (Rodrigues et al, 2019). The teaching learning process is expected to be open accessed, unique, active and interactive, learner-centred and to be an enjoyable learning process. E-learning also believed by Garrison (2017) to be able to transform educational context in a positive way. Online class in this study related to the use of technology media to conduct the teaching and learning. Here, the media can be phone, computer, laptop or tablet. The platform in this research is chat application, video meeting app and learning management system.

This research intended to respond the change of educations system and all its phenomenon. Above previous studies revealed learning contract in conventional or face to face physical classroom setting and mostly conducted in university level. This study focuses on online class and conducted in junior high school level which in this pandemic situation then forced to be more independent and expected to be more self-directed. In addition to the research of learning contract, this study tried to reveal learning contract existed in online class and its impact on students learning behavior. To maximize the use of distance learning, it is an urge to identify what kinds of learning contract mostly applied in online class.

\section{METHODS}

10 teachers (7 females and 3 males) from 3 schools were invited to participate in this study. Descriptive qualitative research is used as the approach to conduct this study. Qualitative approach is used in order to investigate a problem of certain phenomenon so then it can be understood clearly (Cresswell, 2012). A questionnaire and semi structured interview were used to obtain the data. In the questionnaire and interview session, several questions used to collect teacher's opinion and perceptions of learning contract in online teaching context. The data then being analyzed descriptively using thematic analysis method to answer the following two 
research questions: 1) what learning contract exist in online class? (2) how is the effectiveness of the implementation of online learning contract based on teacher's perspectives?

\section{RESULTS AND DISCUSSION}

The following descriptions are related to the finding of the study to answer the research questions of this study, includes the type of online class learning contract existed and its effectiveness based on teacher's perspectives.

\section{Type of learning contract exist in online class}

Based on the data obtained, from 66 teacher's responses, there are 12 types of learning contract exist in online class. The most common type is related to student's obligation to follow all teacher's instruction. The data obtained from questionnaire and interview related to this question is presented on the table below

Table 1. The Most Common Online Learning Contract

\begin{tabular}{|c|c|c|}
\hline $\begin{array}{l}\text { Learning } \\
\text { Contract }\end{array}$ & Variations & $\begin{array}{l}\text { Number of } \\
\text { responses }\end{array}$ \\
\hline $\begin{array}{l}\text { Students } \\
\text { follow all } \\
\text { teachers' } \\
\text { instructions }\end{array}$ & $\begin{array}{l}\text { Students should turn on camera on } \\
\text { virtual writing } \\
\text { Students follow all teacher's } \\
\text { instructions } \\
\quad \text { Total }\end{array}$ & 12 \\
\hline $\begin{array}{l}\text { Students talk } \\
\text { with } \\
\text { permission }\end{array}$ & $\begin{array}{l}\text { Students talk only by teacher's } \\
\text { instruction } \\
\text { Students have a chat discussion by } \\
\text { teacher's instruction } \\
\text { Total }\end{array}$ & 1 \\
\hline $\begin{array}{l}\text { Students must } \\
\text { be behaved }\end{array}$ & $\begin{array}{l}\text { Students act politely } \\
\text { Students talk politely } \\
\text { Total } \\
\end{array}$ & $\begin{array}{l}3 \\
1 \\
4\end{array}$ \\
\hline $\begin{array}{l}\text { Students } \\
\text { respect } \\
\text { teachers }\end{array}$ & $\begin{array}{l}\text { Students attend online class } \\
\text { Students focus on the class }\end{array}$ & $\begin{array}{l}3 \\
8 \\
11\end{array}$ \\
\hline $\begin{array}{l}\text { Students take } \\
\text { a proper seat }\end{array}$ & $\begin{array}{l}\text { Students should stay in front of } \\
\text { camera } \\
\text { Total }\end{array}$ & $\begin{array}{l}5 \\
5\end{array}$ \\
\hline
\end{tabular}




\section{JLIC}

$\begin{array}{llr}\begin{array}{l}\text { Students } \\ \text { submit }\end{array} & \begin{array}{l}\text { Students submit the assignment on } \\ \text { time }\end{array} & 11 \\ \begin{array}{l}\text { assignments } \\ \text { based on }\end{array} & \text { Students do the assignment by himself } & 3 \\ \text { teacher's } & \\ \text { instruction } & \end{array}$

Total

Students

Students actively participate in class

actively

engaged

learning

14

6

11

3

6

Table 1 displays 66 responses regarding learning contract in online class reported by 10 informants. As shown in table above, there are 12 learning contracts reported by the teachers which then categorized into 8 categories.

First category that will be discussed is related to students follow all teachers' instructions. There are 19 responses related to this category. This category mainly referred to any activities done by students which should be based on teacher's instruction. In this category, learning contract includes student's requirement to turn on their camera on online class and also students should follow every and each teacher's instructions. By turning on camera, teachers will be easier to monitor student's activities. It is also related to ability of teachers to see whether students willing or not to follow step by step of teacher's instructions.

Second category is talking with permission. There are 7 responses related to this category. This category referred to student's written and speaking activities during lesson. In this category, teacher reported that students asked to mute the speaker while other is talking and they could not call out friends or speaking something irrelevant. Another point reported also students are not permitted to have a chat or discussing something out of the class topic in chatroom.

Third category is students must be behaved. There are 4 responses related to this category. Behaved here referred to student's is forbidden to produce verbal speech and also gestures which categorized as inappropriate and irrelevant. Speaking foul 
languages and teasing friend are not permitted during online class. In interview section it was revealed that teachers asked students to mute the speakers and talk only by teacher's permission and students cannot give inappropriate comments about other student's performance or answers.

Fourth category is respecting teachers. There are 11 responses related to this category. Here this category referred to the contract related to student's attitude. Students should attend the class based on the schedule and avoiding to be absent or being late attending the virtual class. In this category, teachers also reported that they made a contract that students should inform teacher about their lateness or absence only by parents' acknowledgment. This category also covers about the agreement between teacher and students that they both should focus on the class and forbidden to have any drinks or foods and avoiding to have a conversation with other person such as parents, siblings or friends during online class

Next category is online class seating agreement. There are 5 responses related to this category. This category referred to student's agreement to activate their camera during lesson and cannot disappear from the camera or even ask someone else to stay on camera.

Another category is related to assignment agreement. There are 14 responses related to this category. In this category, teacher reported that students should agree to follow all rules of online assignment submission. This agreement to avoid students from failed of assignment submission. This category also related to agreement related to overdue assignment and plagiarism.

The following category is related to agreement that students should actively participate during lesson. Active participation here related to student's ability to follow step by step of teacher's instruction and also actively participate in class or group discussion

Based on the data obtained and among various learning contract reported, agreement about student's obedience of following teacher's instruction become the most common learning contract in distance learning. A teacher commented that

".....following all teacher's instructions is the key of a successful learning both conventional and online learning. We need all students to do step by step instruction given to make the lesson well delivered and all the learning outcomes possibly achieved" (Teacher 02) 


\section{JLIC}

The result of teacher's perspective and attitude about the implementation of learning contract is presented on the table below

\section{The Effectiveness of Learning Contract in Online Class}

A 12 questions questionnaire used to obtain the data related to teacher's perspective about the effectiveness of learning contract implementation in online class. Based on the data analysis, it is found that most teachers believe that learning contract in online class can improve online class success, since it can control student's misbehavior, improve student's discipline and student's achievement.

Based on the result of first question, it can be seen that most of teachers believe that the implementation of online learning contract could increase online class effectiveness. The results of question three indicates that all of the participants are agree that the implementation of online learning contract provide learners with opportunity to improve the successfulness of online class learning. Question four asked participants whether the implementation of online learning contract should be done by other teachers or not. It reveals that almost all of the participants, $95,69 \%$, agree with the idea that the implementation of online learning contract should be used for teachers to help students improving their achievement.

Table 2. Teacher's Beliefs on The Value of Implementing Online Learning Contract

\begin{tabular}{cccc}
\hline No & \multicolumn{1}{c}{ Statement } & Agree \% & Disagree \% \\
\hline 1 & $\begin{array}{l}\text { I believe that the implementation of } \\
\text { online learning contract has a good } \\
\text { value }\end{array}$ & 87,68 & 12,32 \\
2 & $\begin{array}{l}\text { I believe that implementation of } \\
\text { online learning contract can } \\
\text { improve student's achievement }\end{array}$ & 95,69 & 4,31 \\
3 & $\begin{array}{l}\text { I believe that implementation of } \\
\text { online learning contract gives } \\
\text { opportunities to improve online } \\
\text { class success }\end{array}$ & 96,67 & 3,33 \\
$4 \quad \begin{array}{l}\text { I think that teachers need to } \\
\text { implement online learning contract } \\
\text { to increase online class effectiveness }\end{array}$ & 95,76 & 4,24 \\
\hline
\end{tabular}


Table 3 shows that most of teachers do not agree with the statement that online learning contract cannot improve online class successfulness. In other statement, eighty percent of teachers stated that this implementation of learning contract can support student's online learning, because this implementation of online learning contract provide teacher's and student's role during class. Eighty eight percent of teachers also disagree with the idea that implementation of online learning contract is needs much time allotment. Question eight indicates that most of teachers do not find difficulties to implement online learning contract. Generally, teachers showed to have a good attitude to their learning contract implementation.

Table 3. Teacher's Attitude Toward the Implementation of Online Learning Contract

\begin{tabular}{clcc}
\hline No & \multicolumn{1}{c}{ Statement } & Agree \% & Disagree \% \\
\hline 1 & $\begin{array}{l}\text { I believe that I cannot improve the } \\
\text { online class success by } \\
\text { implementation of online learning } \\
\text { contract }\end{array}$ & 25,74 & 74,26 \\
2 & $\begin{array}{l}\text { I believe that implementation of } \\
\text { online learning contract cannot } \\
\text { support student's online learning }\end{array}$ & 12,98 & 87,02 \\
$3 \quad \begin{array}{l}\text { I believe that implementation of } \\
\text { online learning contract can be time } \\
\text { consuming }\end{array}$ & 11,54 & 88,46 \\
4 & $\begin{array}{l}\text { I find it difficult to implement } \\
\text { online learning contract }\end{array}$ & 26,65 & 73,35 \\
\hline
\end{tabular}

Table 4 proofs that most of teachers are considering the fact implementation of online learning contract is an effective way to improve student's pronunciation. 


\section{JLIC}

Table 4. Online Learning Contract Effectiveness

\begin{tabular}{clcc}
\hline No & \multicolumn{1}{c}{ Statement } & Agree \% & Disagree \% \\
\hline 1 & $\begin{array}{l}\text { I believe that the implementation of } \\
\text { online learning contract can } \\
\text { decrease student's misbehaviours }\end{array}$ & 85,98 & 14,02 \\
2 & $\begin{array}{l}\text { I believe that the implementation of } \\
\text { online learning contract is not too } \\
\text { effective for online learning }\end{array}$ & 13,33 & 86,67 \\
3 & $\begin{array}{l}\text { I believe that the implementation of } \\
\text { online learning contract promotes } \\
\text { student's discipline }\end{array}$ & 95,62 & 4,38 \\
4 & $\begin{array}{l}\text { I believe that the implementation of } \\
\text { online learning contract cannot } \\
\text { promotes successful online learning }\end{array}$ & 13,33 & 86,67 \\
\hline
\end{tabular}

Question nine was asked to teachers to reveal how they feel about the implementation of online learning contract could decrease student's misbehaviors in online learning. The results indicate that most teachers feel that the implementation of online learning contract increase student's discipline. Question ten indicates that majority of teachers stated that the learning contract is an effective way for online learning.

Based on the data come from teacher's point of view, this study tried to define types of learning contract, and to identify its effectiveness. Table 1 presents 19 online learning agreements which categorized into 8 categories. Among those categories, the most common is agreement of student's obedience to follow teacher's instructions, then followed by agreement of assignment submission. Teachers considered those agreement as a good way to increase student's discipline and expected to decrease student's misbehaviors during online class.

This study reveals a unique aspect of distance learning, in this case is teacher-students learning contract. Although the learning contract agreement categories are quite similar with the previous studies found in conventional class, distance learning contract showed unique phenomena. Related to agreement of respecting teachers in the previous studies (Öztürk, 2017) was regarded as learning contract which students may not busy with 
personal stuff, reading, doing other assignment, drawing and playing phone. In distance learning. busy with phone is not an issue anymore because students mostly use their personal phone for the distance learning. In online learning contract is more about students should avoid distractions from their surroundings such as TV, parents or sibling's talking and other things unrelated to teacher's instruction, such as playing with pen, paper, toys, etc.

Learning contract reported in this category were teachers asked students turning on the camera during virtual class. This agreement aims to make teacher able to monitor student's activity. With particular focus on distance learning, teacher's monitoring is limited on student's activities behind the camera on virtual meeting. Teacher can monitor only based on what it looks from the camera frame.

Similar to other studies (Granero, et al, 2020), verbal harassment appeared to be a serious misbehaviour which was disruptive, such as speaking inappropriate language as well as tease other students. That is why having learning contract which promotes student's attitude and politeness is urgently needed. This agreement done to avoid misbehavior which mostly happened in chat room on discussion session. As Sumiarsih (2019) found that learning contract able to decrease student's misbehavior and help students to learn better and faster, the learning agreement done by teachers in this research found to be a good way to solve the lack of sympathy among students which is believed as the reason behind these aggressive attitudes.

Learning contract which manage student's seating also reported by (Öztürk 2017). While in conventional teaching and learning, this seating problems identified as student's movement from their seat, in distance learning, this agreement identified as student's attitude in frame or camera, so then teachers could not monitor their position. This agreement also discusses about a phenomenon that students often ask someone else such as their parents or siblings to substitute their position in front of the camera. Teachers reported that they expect students to obey their online class rules of virtual meeting, that is to turn on the camera and stay on the frame.

The following online learning contract agreement which also done by teachers is related to assignment submission. As the previous studies reported by Frank and Scharf (2007), same as 


\section{JLIC}

conventional classroom learning, students expected to submit their assignment on time. In this study, the findings were quite similar, teachers reported the online learning contract made to avoid student's late submission of assignment and also plagiarism. Data from interview showed that the agreements made to increase students' discipline in submitting their assignment so then they will not submit it overdue or not in the time expected such as in the middle of the night and weekend. This kind of attitude not only affect student's performance but also disturbing teacher's schedule and personal life.

Self-directed as one of the aims of learning contract also found by a research done by Chyung (2007); Ismail and Yusof (2007) which revealed that students felt independent, more selfdirected and motivated by given a learning contract. This aim also considered by teachers to make an agreement related to student's active participation in online classroom. By having an agreement of student's participation on class discussion, teachers expect it could promote student's willingness to learn, to be active and do their best to achieve learning outputs and outcomes.

Although this study able to reveals some unique findings, some limitation also being a concern. First, since this study only involved 10 teachers from 3 schools as participants, representativeness become an issue. Second, as only this study focused on teacher's perspectives, it would be more comprehensive if student's perspective also can be obtained. For future study, teachers distance learning management class and strategy on managing learning contract could be done to complete the findings.

\section{CONCLUSION}

Based on the discussion above, it can be concluded that learning contract found in this research are compliance to teacher's instructions, permission to talk, student's behavior, respecting teacher, seating and attendance, and assignment submission. The most common online learning contract stressed by teachers are compliance to teacher's instructions, assignment submission and respecting teachers. Since this study's limitation that only took the data from teacher's perspectives, future research on this topic might consider student's perspective related to the implementation of the online-class learning contract. 


\section{REFERENCES}

Chyung, S. (2007). Invisible Motivation of Online Adult Learners During Contract Learning. Journal of Educators Online, 4(1) Retrieved February 18, 2021 from http://www.thejeo.com/Volume4Number1/ChyungFinal.pdf

Creswell, J. (2012). Research Design Pendekatan Kualitatif, Kuantitatif, dan Mixed. Yogyakarta: Pustaka Pelajar.

Rodrigues, H., Almeida, F., Figueired, V., \& Lopes, S.L. (2019). Tracking E-Learning Through Published Papers: A Systematic Review. Comput. Educ.

Frank, T. \& Scharff, L. (2013). Learning Contracts in Undergraduate Courses: Impacts on Student Behaviors \& Academic Performance. Journal of the Scholarship of Teaching \& Learning, 13(4), 36-53.

Garrison, D.R. (2017). E-learning in the 21st Century: A Community of Inquiry Framework for Research and Practice, 3rd ed. Routledge: New York, NY, USA.

Granero, A; Baños, R; Baena., \& Martínez, M. (2020). Analysis of Misbehaviours and Satisfaction with School in Secondary Education According to Student Gender and Teaching Competence. Frontiers in Psychology: Journal of Education Psychology Ed 2020

Ismail \& Yusof. (2017). Exploring the Use of Learning Contracts for Language Learning. Universiti Teknologi Malaysia Institutional Repository

Lai, C. (2007). The Influence of Learner Motivation on Developing Autonomous Learning in an English-for-Specific-Purposes Course. Asian Journal of English Language Teaching, 8

Lewis, J. (2004). The Independent Learning Contract System: Motivating Students Enrolled in College Reading Courses. Reading Improvement, 41(3), 188-194

Little, E. (2005). Secondary School Teachers' Perceptions of Students' Problem Behaviours. Educational Psychology, vol. 25, no. 4.

Masdinah A. M. Y. \& Abdul Halim A. R. (2004b) Training Students to be Autonomous Learners Paper presentation at the 1st International Language Learning Conference Universiti Sains Malaysia 16-18 December 2004

Purwanta, E. (2015). Modifikasi Perilaku: Alternatif Penanganan Anak Berkebutuhan Khusus. Yogyakarta: Pustaka Pelajar 


\section{JLIC}

Schwarzer D., Kahn, R.E., \& Smart K., (200o) Learning Contracts and Team Teaching in a University ESL Writing Class. The Internet TESL Journal. 6(10)

Sumiarsih. (2019). The Effectiveness of Behavioral Contracts Techniques to Reduce Off Task Behavior In Class V Slow Learner. Journal of Widia Ortodiaktika. State University of Yogyakarta.

Sun, R., \& Shek, D. (2012). Student Classroom Misbehaviour: An Exploratory Study Based on Teachers' Perceptions. Developmental Issues in Chinese Adolescents Journal Volume 2012

Yusuf, M. \& Legowo, E. (2007). Reducing Student's Learning Misbehaviours through Behavioral Modification Approach. Jakarta: Departement of National Education: Department of Higher Education. 